ことが判明した。

この研究は, プログラム学習が, 学習の方法として有 効であるばかりでなく，「授業研究」の方法として有効 であることを示したもので, ティーチング・マシンの理 論家が主張していることを実証してみせた点，大きな意 義をるつるのである。

これに対して，3つの質問があつた。

第 1 は, 三角形求積を教えることの意味がはつきりせ ぬ, という批判であつた。これはもちろん学習指導要領 にあるのだが，そのことは，三角形求積の計算の習熟が 目的なのか, 理解が目的なのかはつきりせぬ，という意 味でもあったが, より多く,ティーチング・マシンでは 学習の目標がはっきりしていないと, 教育 (哲学) 的に 非常に危険である，という警告の意味であつた。

第 2 は，第 8 報告について，選択法がよい結果を生ん だことに関連して出たものである。選択法は答えがすで に呈示されているという点で, 一種の「教授」なのであ る。完成法ではヒントしか与えられ奴選択法では答え
がまるごと呈示される。この点から，選択法は，よりく わしい「教授」だということができる。これは，したが つて, 生徒のよりよい成績を生み出すことは当然なので ある。しかし他方，いつも選択法をやることを習慣づけ られる子どもは, 自発的制作の態度を忘れてしまうかも しれぬ。ここにプログラム学習の大きなワナがある。こ ういう質問であつた。

第 3 は知能のひくいものが，プログラム学習で大きな 効率をるつことを承認するとして，それならば，プログ ラム学習によつて啓示される低い知能とは，ある作業を 「より技そく学習する」能力, と解してよいかという質 間であつた。これはブランチング（枝わかれ）の構想と も関連する。ブランチングをみとめ方式だと，知能と は，作業の速度の関数に帰することになる。（しごとの 質はちがいがなくなるので)

おわりの時間に追われ，未解決の問題をのこして，討 論を中止しなければならなかつた。

（波多野完治・大崎サチエ）

\title{
17. 視聴覚教育・テレビ
}

\section{2，633 テレビの児童におよばす影響（II）}

依田新 肥田野 直 吉田泰子
(1)芝 祐 順 波多野誼余夫 筒井健雄
(東京大学)
(2)都 筑 秀行(東京都大田区大森第一中学校)

(1) 視聴時に抢けるGS R

$\mathrm{TV}$ 視聴中の児童の G S R を指䌘として，TVの内容 と児童の情動変化との関係をとらえることを目的として いる。西部劇とホームドラマそれぞれ1本を, 小中学生 （ 5 年と 2 年）男女合計 156 人にみせた。G S Rはコンデ ンサー回路を使用。結果はフィルムを約15秒(平均)の長 さのシーンに分割し，そのシーンの中である基淮以上の G S Rの変動があったか否かを測度として整理。2 本の フィルムの間に差はあったが，統計的に有意 (5\%で) ではなかった。その他の分散分析の結果は, 性差が有意 である以外有意差を示さなかつた。フィルムの内容分析 によるシーンごとの評定結果と G S R との関係ではなご やかな, 楽しい場面が，より多くの変動を示していた。

（2）登場人物の特性と相互関係の理解

(1)と同様の西部劇, ホームドラマを, 中学 3 年生男女 194 名に集団視聴させ, 視聴直後に質問紙調査を行なつ た。結果の整理は, 1.フィルム内容の理解, 2 . 主人
公の行動に対する評価，3．登場人物の性格の理解，の 3 点にしぼり検討を加えた。そのうち特に問題として取 りあげられるものは，(1)劇の外面的な進行は活とんぞ確 実に理解されているが，登場人物の心理的な動きは必ず しるとらえられていない。(2)このため, 主人公の行動に 対する評価も, 単純・一面的で, 葸藤場面の性質が理解 されていない。(3)そのほかの登場人物の性格についても ステレオタイプ的なとらえ方が多い，などである。

\section{4-636 テレビの児童に及ぼす影響（III）}

\section{——幼児・児童のテレビ視聴実態調査}

\section{依田新 (1)肥田野直 (2)井上健治 (3)加藤礼子 (東京大学)}

\section{(1) テレビ視聴の時間と内容}

東京都内の幼稚園 2 年保南年少児, 小学校 1 年生それ ぞれ約2000名について，テレビ視聴実態調查掞よび生活 時間調査（いずれる母親に記入依頼）を実施し，年令・ 性・親の社会階層にしたがって結果を整理した。1１ 1 日のテレビ視聴時間の平均は100〜150分 (平日)， 120 〜180 分 (日曜) で, 小学生は幼児より多く, 男児は女 児より多い。また, 社会階層の低い家庭の子どもは, 高 い家庭のこどもより多く視聴する傾向がある。2．視聴 する番組は，いわゆる「こども向け番組」が圧倒的で， 


\section{発表 要旨・討論 の 概 要}

ことにマンガ, 童話, 呪童劇の類が多い。おとな向けド ラマ(一部の西部劇, スリラーを除く), 歌謡曲, コメ ディの類は少ない。

(2) テレビ視聴態度と親の統制

3、テレビを設置してある部屋と，こどもが勉強（遊 び）をする部屋が同じである場合が多く，視聴量を增加 させる大きな社会的条件になつているものと思われる。

(ことに低階層)。4 . 幼児においてもすでにダイアル 権を持つことが多くあり，積極的視聴が行なわれること を示す。5.しかし，視聴の際には必ずテレビに没入乙 ているといらわけではなく, 番組によっては遊び半分に 「軽く」視聴することも多い。6。こどもの教育とい5 面からの親のテレビ観は, 好意的・中立的なものが相半 ばし, 非好意的なものは少ない。また, 親は「知識の源 泉」にテレビの教育的機能を最も多く見出し, 反面, お となの世界を子どるに示すことに危惧を抱いている。

\section{(3) テレビ視聴と生活時間}

指定した 2 日間にお斿る起床から就寝までの，子ども の行動の内容について母親が記入した生活時間調査表か ら，テレビ視聴が子どもの生活のパターンにどのような 影響を与えているかを検討した。両日の午後のみについ てそれぞれ 105分を境に，テレビを多く視聴した群（多 テレビ群) と，少なく視聴した群 (少テレビ群) とに分 村, 両群の生活時間の構成を比較した結果, 外出々睡眠 は少テレビ群に多いことが見られたが, 他の行動にはほ とんど差がないことがわかつた。他の諸結果とも照らし 合わせて,テレビ視聴が重要な行動（睡眠を除く）を規 定するというよりも，むしろ，テレビ視聴時間は「特に 何もしていない」時間に代るものであると考劣られる。

\section{7, 638 学習指導における視聴覚教材の効果 について}

城戸幡太郎(東洋大学)
(1)佐々 剛(立教大学)
(2)堀 内 敏 夫(東京学芸大学)
宮 崎 孝一(国立教育研究所)
最上 太門(" " 1 )
高 桑 康 雄(国学院大学)

（VII） 小段階に構成されたスライドの学習効果

総花的な市販のスライドに対して, 単元のポイントを 小段階に構成したスライドによる学習の効果を見ようと して，「電磁石の理論とその応用としての電鈴のなる理 由」を学習させるために, 26コマに構成したスライドを 作った。比較教材（言語教材）として同程度に構成した プログラム・シートを用いて, 既習の 6 年生と未習の 5
年生に実施した。結果は 6 年生においてはスライドの効 果の方がすぐれ, 学習後 1 か月にててなお, 事前テスト の35\%增の効果をあげている。1か月後のテストにおい て 6 年生の平均点 $64.8,5$ 年生 62.6 点で, 未習者に対す る30分のスライド映写がこの程度の効果をあげているこ とから，この種のスライドの効果が期待できる。

（VIII）カット場面の転換による児童の理解・推理に関 する研究

目的・方法は大会プログラム参照。結論 1 . カットに よる新場面が前場面・前の文字刺激と論理的つながりが ある場合でも, 生活経験がそしい児童には, 誤つた理解 部分的理解が多く, 全体的理解や帰納的・演繹的推理と は $5 \%$ 水淮で有意の差があり，坚童のレディネスにると つく新映像構成が必要である。2. 交字刺激 (字幕) か ら映像一のカット転換は, 抽象的表現から具体的・特殊 的表現への刺激系列の転換であるのに, 交字と映像との 関係把握が欠如し, 中学年児童の理解が困難である。3 映像のアップによる抎大図形での新場面は教枋フィルム TVでしばしば用いられるが，中学年先童のレディネス を考虑しないと, 誤つた認知, 部分的理解がなされる点 注意を要する。

\section{討 論 の 概 要}

発表は，大きく2つに分類できた：1）依田新を中心 とした「テレビの児童に及ぼす影響」の研究と，2）城 戸幡太郎を中心とした「学習指導における A V 教材の効 果について」の研究とである。前者では, 一方で, 西部 劇とホームドラマに対して，GＳRによる反応と内容理 解の分析がおこなわれ，他方，視聴实態および生活時間 についての調查分析がおこなわれた。後者では, 電磁石 の原理とべルについて, 小段階構成によるスライドの学 習効果を分析し, 他方, カット場面に上る新映像の理解 ・推理が分析された。

これらの研究発表にみられる特徵としては, 依田らの 研究が「影響」の現状を種々な角度から分析して総合的 な姿を浮かびあがらせ上うとする，いわば一般心理学的 方向からのアプローチで女るに対して, 城戸らのほうは プログラミングを念頭においたいわば教育的方向からの アプローチであるといえようか。実践的な課題について の教育心理学的アプローチのしかたの 2 つの方向を特徵 的に示しているとい方よう。

しかし, 質疑討論からもらかがえるように, この種の 研究はまだ方法・手続き上の問題に限局された段階にと ぞまつている観もあるといえよう。

質疑討論の概要はつぎのとおりである。 


\section{教育心理学年報 第 2 集}

山本（立教大）：GＳＲの波の変動と内容との関係はな いか?

芝：フィルムがあたえられているので，長短のコントロ ールがむずかしい。Positive と Neutral の間には，P のほうが変動大とはいえる。P ては方法を改めないといけないと思う。GS Rについて は, 個人差大きく,フィルム差・学年差は出ない。性差 の及出た。

小池（東京学芸大）：階層の分汓方が重要なポイントと なると思うが，特別の理由があるか？ また，質間紙記 入の母親とは有職者か主婦か?

肥田野：階篔別はくわしい潐拠はないが，はじめからか たよつている。常識的に分计た。IホワイトカラーとIII ブルーカラーおよびII中間的なものとに分けた。企業主 はIIに入る。

加藤：母親の職業は掞さえていないが，主婦と考えてよ い。有職者のデータは不備だつたから。

古籍（福島大）：子ども自体の態度レベルでおこなわれ ていないか?

肥田野：TVに対して子どもがどんなふうにみているか は小5中1につき昨年行なつた。今回はその点はみてい ない。

古籍：番組付対する態度はわかつているが，親の T V 観 との関係泳どうか？

肥田野 : 昨年, 読書等と T Vの位置づけの順位をとつて みた。

菊地（福島大）：analyser は抄す子と括さ好がいると 思うが, GSR そ analyser の有効性はどうか？

芝 : analyser には知間がある。等心にみていると analyser を忘れ，analyser に熱心だと見方がかわる。G S R つ计た影響はほとんどみられ奴，潜時の間題あ り，ホームドラマでだんだんわかつてくる場面など反応 が扔くれる。G S Rが無理か，それとも方法により有效 になるかも見当ついていない。

宮田（学習研究社）：小段階に上る場合, 生徒の反応を とつたか？通過率は？

堀内：スライドの場合，いちいち反応はしらべられ欢が いいす法があれば教えられたい。

村瀨（名古屋大）：反応は，同じ罒親か，矅日により別 々か? 回収率は?

井上：生活調查は，使え妨ータが多いので，600 分中 400 分を最低限の規準とした。金・日を別々にしたので 数はくいちがつた。回収率はかなりだが，使えたデータ は少ない。

続（名古屋大）：兄弟や祖父母のある子かどうかの分類
とからみ合わすべきでないか？

井上：間にあわなかつたが，そのと抢りだと思う。

村瀬：生活調査を金・日で分汁ているが，ともにTVを みるものについて分汁るべきだと思うが？

肥田野：TVをみることにより，生活時間の構造がぞう 変わるかをみたかつた。そう分汁るべきだつたと思う。 村瀬：子どものパターンにどう影響するかが目的となる のでないか？

肥田野：TV空みている時間そのものがぞうかについて はこのデータではいいきれぬ。

城戸 : スライドと言語教材の效果比較実験としては, プ ログラミングのしかたそのものを変えてやる必要がある と思う。学研などではどうか?

宮田：まだやつてないが, 特殊な analyser で段階の大 きさと通過率などについてみるとどうだろう？反応を 1 分後にさせるから秒後かなど，フィードバックのこと る研究したい。

山本：その特殊な analyser とは？

宮田：スライドと説吸亮シンクロナイズさせ, 選択した ものを別々の波長で同時記録させる。

多田（東京教育大）：A V 提示と言語提示で, 両者のプ ログラミングが同じ程度になつているかどうかをくらべ ぬとだめだと思うが?

佐及木：うけとる側がどうちがうかとステップのちがい、 を同時にどうとらえるかわからない。

多田：雨者のプログラミングをいらいらにとり，その得 点が同じだということをおさえたら？

佐及木：罙の程度ならいいが，簃密にはどこでおさえる べきかが問題だ。

布留 $(\mathrm{NHK})$ ：視聴時間の多少の畾慣性につき, 各睢 日にわたつてしらべた。相関は，隔週で 0.8 , 夏冬の 7 か月間ぐらいで 0.6，1週間とある1日とではどの矅日 も 0.8 ，2 日とではより大， 3 日間とると0.95ぐらい。 ある1日とつてもだいたいわかるのでないか。analyser とあとの質問との間には高い相圆がある。だいたいわか るのではないか。また練嘼浅よる。

山本：analyser については艺う心配いら始のではない か。多くの子どもが好覀をいままでのとくらべて大きく みればよい。普通児は感情なコントロールするし，非行 少年はでき欢ということもあるようだ。そうした内容の ほうを東大でも分析してほしい。

井上：布留氏の調査はどんなのか？

布留: 一種の日記法で, 時刻目盛りに䍿朝記入させる。 番組リストと比較して，より正確だ。

村瀬：視聴時間の相関は分析の手段であつて, T V 視聴 
が原因か, 生活原理があつての結果としてTV時間が長 くなるかを区別する要がある。 肥田野：今後そうした分析をしたい。

乾（法政大）：analyser で熱中すると制止がかかるの ではないか。ガムでもかませて観察するとわかる。指の 訓練が自動的にできるまではまだ使えない。AV と言語 で，分布がちがうものを比較するのはどうか。 山本：analyser が信用できぬというのは?

乾：指は意識的応答だから，訓練されているならいいが 構えがちがつたりする。ガム方式を戦密にやつたほうが はるかに有効ではないか?

肥田野：analyser は大量の集団として傾向的に把握す るには有効と思う。少数実験で個々人の対応をみるには 間題があると思う。

芝：意識的であることはよくわかる。もうひとつ, 時間 のおくれがあるので, 短時間の区切りあるるのには問題 があると思う。

乾：ガムはアメチョコ時代に考光たものだが, analyser ができて使つたがうまくいかない。行動観察の見出しを うまく作つて, 観察者訓練をするほうがよいと思う。 堀内：ピストルがなると G S Rがあがるが回を重ねると あがらなくなる。context の問題でないか。analyser は 補助的なものだし，GSRでもその解釈に苦しむ場面が まる。

一：脈搏や呼吸の影響をどうみるか？G S Rは呼吸 をつめたためで，場面とはすでにズレているというよう な点。集団的にいい方法はないか？

芝：そんなコントロールはしてないが，そうした限界を こみにしたものしかとれぬのではないかという感じがす る。

中川（法政大）：ただ頻度だけをとったか？

芝：手間がかかるのと，シーンの解釈がおさ光られない のとで，ままりこまかいことをしてもだめと考えた。内 容の把握がわからぬので。

続：1年に 7-8 回TV-スタジオに生徒を入れてやつて みたが，番組はストーリーであるに反し，場面に区切る のは実験者の側からだから，全体の再構成のしかたが問 題だと思つた。山がすぎると，第 2 の山ではもうもりあ がらない。やはりシーンへの反応は time-series でとら えぬといけないと考觉る。

（津留 宏・川口勇）

\section{8. 職業と産業}

\section{1 職業変遷の経歴的研究}

\section{伊藤惣右衛門 (山形大学)}

進路および職務内容の経歴的な変遷を，最初の希望意 識と関連させつつあとづケていこうとすることが目的で ある。そのために農村地域における青年 162人を対象と して調査した。まず中学在学中の希望意識を各個人ごと にしらべ, それから卒業直後, 2 年後, 5 年後, 都合 3 回家庭訪間によるインタービューを行なつた。(1)進路に ついては, $a$ a a b 型, $a \mathrm{~b} b$ 型, a a a a 型が最も 多く,この 3 つで約 $60 \%$ を占める。希望意識との一致度 は, 卒業直後と 2 年後に大きく，5年後において小さ い。(2)職務内容については, a a a a 型と b b b c 型が 多くあらわれるが, 職業経歴は年月とともに最初の希望 から離れた方向に変遷していく傾向がある。ことに男の 場合著しい。

\section{2 青年の職業生活に対する}

\section{態度についての研究}

——都市青年と農村青年の比較

中島 力(立教大学)

目的：青年が職業生活での職場における拘束された生 活と，自由時間での生活のおのおのについて，またとの 両者の関係についてどのような意見を持つているかを調 査する。特にここでは農村中学生と都市中学生の比較を 試みる。対象 : 東京都内の中・高校 3 年生, 神奈川県の 農村の中・高校 3 年生および東京都の大学生。方法 : 質 問紙法。結果：学歴，出身を問わず，仕事よりも白由時 間中の個人生活を重視し，職業をそのための手段と考え る傾向が強い。しかし農村中学生のうち就職希望者は, 仕事の方をより重要視する意見が他の場合より多い。か れらは職場で人間関係より仕事を重要視し，自由時間で は対人関係を重視する傾向があり, 都市青年はむしろ逆 の傾向を示す。 